\title{
Effects of Melatonin on the Growth of Radish Seedlings under Salt Stress
}

\author{
Yuting Jiang ${ }^{1, a}$, Dong Liang ${ }^{2, b}$, Ming'an Liao ${ }^{1, c}$ and Lijin Lin ${ }^{2, d^{*}}$ \\ ${ }^{1}$ College of Horticulture, Sichuan Agricultural University, Chengdu, Sichuan, China \\ ${ }^{2}$ Institute of Pomology and Olericulture, Sichuan Agricultural University, Chengdu, Sichuan, China \\ a2863170989@qq.com, b756141959@qq.com, 'Iman@sicau.edu.cn, dllj800924@163.com \\ ${ }^{*}$ Corresponding author. Yuting Jiang and Dong Liang contributed equally to this work.
}

Keywords: Melatonin; Growth; Radish; Salt

Abstract: A pot experiment was conducted to study the effects of melatonin (MT) on the growth of radish seedlings under salt stress. MT increased the biomass, chlorophyll content and antioxidant enzyme activity of radish seedlings under salt stress. When the concentrations of MT were 50, 100, 150 and $200 \mu \mathrm{mol} / \mathrm{L}$, the activity of SOD improved by $17.26 \%, 35.20 \%, 18.97 \%$ and $17.27 \%$, respectively, compared with the control, and the activity of CAT improved by $118.44 \%, 132.55 \%, 114.82 \%$ and $103.69 \%$ respectively. When the concentration of MT was $100 \mu \mathrm{mol} / \mathrm{L}$, the biomass, chlorophyll content and antioxidant enzyme activity of radish seedlings got the maximums. Therefore, MT could relieve the damage of radish seedlings under salt stress, and the dose of $100 \mu \mathrm{mol} / \mathrm{L}$ was the best.

\section{Introduction}

China is one of the most serious salt-affected countries in the world, and the total area of saline soil is about 36 million hectare, accounting for $4.88 \%$ of the available land area [1]. Not only the soil resources are wasted, but also the crop yield has been seriously affected, which threatens the sustainable development of Chinese agriculture [2]. Therefore, the development of salt tolerance of vegetables study has become an important issue in agricultural production [3].

Melatonin (MT) plays a role as an antioxidant defense system in unicellular organisms, and is mainly concentrated in mammals to regulate the rhythms and accomplishing various immune responses in early study [4]. MT is also found in plants, and has many physiological functions such as protecting chlorophyll, regulating plant photoperiod, similar to IAA growth regulation [5-7]. In recent years, more and more studies have been done on MT in higher plants. Exogenous MT treatment on Isatis indigotica seeds can increase the activity of antioxidant enzyme and alleviate the stress on seedlings growth under cold stress, and may stimulate plant growth by influencing plant IAA levels [8]. Exogenous MT has a certain effect on the germination of rice seeds under cadmium stress, which could improve the germination rate and germination potential and promote the growth of young roots and shoots [9].

Radish is a widely distributed vegetable in China, and has many varieties and large cultivated area [10]. In this study, we planted radish seedlings in salt stress environment, and studied the effects of MT on the growth of radish seedlings under salt stress, which could provide the reference for its application in vegetables.

\section{Materials and Methods}

Experimental Design. The vermiculites and pearlites (1:1) were put into polyethylene pot $(10 \mathrm{~cm}$ high, $10 \mathrm{~cm}$ in diameter). Three uniform radish seedlings with three leaves expand were transplanted into each pot in November 2015, and 5 concentrations (0, 50, 100, 150 and $200 \mu \mathrm{mol} / \mathrm{L})$ of MT with 3 replicates were sprayed on the leaves of plants for each pot, respectively. From the third day of transplanting, the Hogland nutrient solutions containing $50 \mathrm{mmol} / \mathrm{L} \mathrm{NaCl}$ were watered every two days, and $30 \mathrm{ml}$ solutions for each pot. When radish seedlings grow two months under salt stress, the upper mature leaves of radish seedlings were collected to determine the photosynthetic pigment (chlorophyll $a$, chlorophyll $b$ and total chlorophyll) contents [11]. The upper young leaves ( $2 \mathrm{~cm}$ in length) were 
collected to determine the superoxide dismutase (SOD) activity, peroxidase (POD) activity, catalase (CAT) activity and soluble protein content [11]. Then, the whole plants were then gently removed, and the plant height, tuberous root length and root length was measured. The roots, tuberous roots and leaves were washed with tap water followed by deionized water, and the biomasses of root, tuberous root and leaf were measured.

Statistical Analyses. Statistical analyses were conducted using SPSS 13.0 statistical software (IBM, Chicago, IL, USA). Data were analyzed by one-way analysis of variance with Duncan's multiple range test $(\mathrm{p}=0.05$ confidence level).

\section{Results and Discussion}

Biomass of Radish. The root, tuberous root and leaf biomasses of radish increased in the all treatments of MT compared with the control (Table 1). With the increase of MT concentrations, the root, tuberous root, leaf biomasses of radish increased when the dose of MT was not more than 100 $\mu \mathrm{mol} / \mathrm{L}$, and decreased when the dose of MT was more than $100 \mu \mathrm{mol} / \mathrm{L}$. The biomass of radish was ranked as: $100 \mu \mathrm{mol} / \mathrm{L}>150 \mu \mathrm{mol} / \mathrm{L}>200 \mu \mathrm{mol} / \mathrm{L}>50 \mu \mathrm{mol} / \mathrm{L}>0 \mu \mathrm{mol} / \mathrm{L}$. When the dose of MT was $100 \mu \mathrm{mol} / \mathrm{L}$, the root, tuberous root and leaf biomasses of radish increased by $48.39 \%(p<0.05)$, $233.78 \%(p<0.05)$ and $13.60 \%(p>0.05)$ respectively compared with the control. Therefore, MT increased the growth of radish, which was suitable for enhancing the yield of radish.

Table 1 The biomass of radish

\begin{tabular}{|c|c|c|c|}
\hline $\begin{array}{c}\text { MT concentrations } \\
(\mu \mathrm{mol} / \mathrm{L})\end{array}$ & $\begin{array}{c}\text { Root } \\
(\mathrm{g} / \text { plant })\end{array}$ & $\begin{array}{c}\text { Tuberous root } \\
(\mathrm{g} / \mathrm{plant})\end{array}$ & $\begin{array}{c}\text { Leaf } \\
(\mathrm{g} / \mathrm{plant})\end{array}$ \\
\hline 0 & $0.062 \pm 0.018 \mathrm{~b}$ & $0.373 \pm 0.069 \mathrm{~d}$ & $1.654 \pm 0.057 \mathrm{a}$ \\
\hline 50 & $0.071 \pm 0.008 \mathrm{~b}$ & $0.717 \pm 0.074 \mathrm{c}$ & $1.816 \pm 0.060 \mathrm{a}$ \\
\hline 100 & $0.092 \pm 0.006 \mathrm{a}$ & $1.245 \pm 0.065 \mathrm{a}$ & $1.879 \pm 0.055 \mathrm{a}$ \\
\hline 150 & $0.091 \pm 0.006 \mathrm{a}$ & $1.181 \pm 0.054 \mathrm{a}$ & $1.862 \pm 0.062 \mathrm{a}$ \\
\hline 200 & $0.090 \pm 0.010 \mathrm{a}$ & $0.933 \pm 0.036 \mathrm{~b}$ & $1.848 \pm 0.054 \mathrm{a}$ \\
\hline
\end{tabular}

Values are means $( \pm \mathrm{SE})$ of three replicate pots. Different lowercase letters within a column indicate significant difference $(p<0.05)$.

Root Length and Plant Height of Radish. MT promoted the growth of radish root, and increased the root length of radish (Table 1). The root length of radish was ranked as: $100 \mu \mathrm{mol} / \mathrm{L}>150$ $\mu \mathrm{mol} / \mathrm{L}>200 \mu \mathrm{mol} / \mathrm{L}>50 \mu \mathrm{mol} / \mathrm{L}>0 \mu \mathrm{mol} / \mathrm{L}$. When the doses of MT were 50, 100, 150 and 200 $\mu \mathrm{mol} / \mathrm{L}$, the root length of radish increased by $14.66 \%(p<0.05), 34.97 \%(p<0.05), 15.24 \%(p<$ $0.05)$ and $14.82 \%(p<0.05)$ respectively compared with the control. The tuberous root length also increased by MT treatments, and order was the same as root length. When the doses of MT were 50, 100,150 and $200 \mu \mathrm{mol} / \mathrm{L}$, the root length of radish increased by $1.23 \%(p>0.05), 10.80 \%(p<0.05)$, $9.81 \%(p>0.05)$ and $4.48 \%(p>0.05)$ respectively compared with the control. The plant height increased with the increase of MT concentrations when the dose of was not more than $100 \mu \mathrm{mol} / \mathrm{L}$, and decreased when the dose of MT was more than $100 \mu \mathrm{mol} / \mathrm{L}$. The order of plant height was the same as root length, too. When the doses of MT were 50,100, 150 and $200 \mu \mathrm{mol} / \mathrm{L}$, the root length of radish increased by $0.42 \%(p>0.05), 6.54 \%(p>0.05), 4.29 \%(p>0.05)$ and $3.52 \%(p>0.05)$ respectively compared with the control.

Chlorophyll Content in Radish. MT treatments increased the chlorophyll content in leaves of radish (Table 3). When the dose of MT was not more than $100 \mu \mathrm{mol} / \mathrm{L}$, the contents of chlorophyll $a$, chlorophyll $b$ and total chlorophyll increased with the increase of MT concentrations, and decreased when the dose of MT was more than $100 \mu \mathrm{mol} / \mathrm{L}$. The contents of chlorophyll $a$ and total chlorophyll were ranked as: $100 \mu \mathrm{mol} / \mathrm{L}>50 \mu \mathrm{mol} / \mathrm{L}>150 \mu \mathrm{mol} / \mathrm{L}>200 \mu \mathrm{mol} / \mathrm{L}>0 \mu \mathrm{mol} / \mathrm{L}$, and the chlorophyll $b$ content was ranked as: $100 \mu \mathrm{mol} / \mathrm{L}>200 \mu \mathrm{mol} / \mathrm{L}>50 \mu \mathrm{mol} / \mathrm{L}>150 \mu \mathrm{mol} / \mathrm{L}>0 \mu \mathrm{mol} / \mathrm{L}$. When the doses of MT were 50,100, 150 and $200 \mu \mathrm{mol} / \mathrm{L}$, the total chlorophyll content of radish increased by $6.88 \%(p>0.05), 11.22 \%(p>0.05), 6.58 \%(p>0.05)$ and $4.26 \%(p>0.05)$ respectively compared 
with the control. The chlorophyll a/b was increased by MT compared with the control, which had the increase trend when the dose of MT was not more than $150 \mu \mathrm{mol} / \mathrm{L}$, and had the decreased trend when the dose of MT was more than $150 \mu \mathrm{mol} / \mathrm{L}$ (Table 3).

Table 2 The root length and plant height of radish

\begin{tabular}{|c|c|c|c|}
\hline $\begin{array}{c}\text { MT concentrations } \\
(\mu \mathrm{mol} / \mathrm{L})\end{array}$ & $\begin{array}{c}\text { Root length } \\
(\mathrm{cm})\end{array}$ & $\begin{array}{c}\text { Tuberous root length } \\
(\mathrm{cm})\end{array}$ & $\begin{array}{c}\text { Plant height } \\
(\mathrm{cm})\end{array}$ \\
\hline 0 & $18.96 \pm 0.41 \mathrm{c}$ & $2.121 \pm 0.144 \mathrm{~b}$ & $14.22 \pm 0.90 \mathrm{a}$ \\
\hline 50 & $21.74 \pm 0.60 \mathrm{~b}$ & $2.147 \pm 0.189 \mathrm{ab}$ & $14.28 \pm 0.94 \mathrm{a}$ \\
\hline 100 & $25.59 \pm 0.72 \mathrm{a}$ & $2.350 \pm 0.079 \mathrm{a}$ & $15.15 \pm 0.82 \mathrm{a}$ \\
\hline 150 & $21.85 \pm 0.55 \mathrm{~b}$ & $2.329 \pm 0.094 \mathrm{ab}$ & $14.83 \pm 0.83 \mathrm{a}$ \\
\hline 200 & $21.77 \pm 0.74 \mathrm{~b}$ & $2.216 \pm 0.129 \mathrm{ab}$ & $14.72 \pm 0.98 \mathrm{a}$ \\
\hline
\end{tabular}

Values are means $( \pm \mathrm{SE})$ of three replicate pots. Different lowercase letters within a column indicate significant difference $(p<0.05)$.

Table 3 The chlorophyll content in radish

\begin{tabular}{|c|c|c|c|c|}
\hline $\begin{array}{c}\text { MT } \\
\begin{array}{c}\text { concentrations } \\
(\mu \mathrm{mol} / \mathrm{L})\end{array}\end{array}$ & $\begin{array}{c}\text { Chlorophyll } a \\
(\mathrm{mg} / \mathrm{g})\end{array}$ & $\begin{array}{c}\text { Chlorophyll } b \\
(\mathrm{mg} / \mathrm{g})\end{array}$ & $\begin{array}{c}\text { Total chlorophyll } \\
(\mathrm{mg} / \mathrm{g})\end{array}$ & Chlorophyll a/b \\
\hline 0 & $1.029 \pm 0.070 \mathrm{a}$ & $0.309 \pm 0.076 \mathrm{a}$ & $1.337 \pm 0.146 \mathrm{a}$ & $3.406 \pm 0.616 \mathrm{a}$ \\
\hline 50 & $1.139 \pm 0.048 \mathrm{a}$ & $0.321 \pm 0.008 \mathrm{a}$ & $1.429 \pm 0.084 \mathrm{a}$ & $3.454 \pm 0.369 \mathrm{a}$ \\
\hline 100 & $1.153 \pm 0.101 \mathrm{a}$ & $0.329 \pm 0.082 \mathrm{a}$ & $1.487 \pm 0.012 \mathrm{a}$ & $3.668 \pm 1.198 \mathrm{a}$ \\
\hline 150 & $1.123 \pm 0.223 \mathrm{a}$ & $0.312 \pm 0.025 \mathrm{a}$ & $1.425 \pm 0.248 \mathrm{a}$ & $3.692 \pm 0.431 \mathrm{a}$ \\
\hline 200 & $1.068 \pm 0.244 \mathrm{a}$ & $0.327 \pm 0.081 \mathrm{a}$ & $1.394 \pm 0.163 \mathrm{a}$ & $3.469 \pm 1.609 \mathrm{a}$ \\
\hline
\end{tabular}

Values are means $( \pm \mathrm{SE})$ of three replicate pots. Different lowercase letters within a column indicate significant difference $(p<0.05)$.

Antioxidant Enzyme Activity of Radish. MT improved the antioxidant enzyme (POD, SOD and CAT) activity of radish in all treatments compared with the control (Table 4). The POD activity of radish was ranked as: $100 \mu \mathrm{mol} / \mathrm{L}>150 \mu \mathrm{mol} / \mathrm{L}>50 \mu \mathrm{mol} / \mathrm{L}>200 \mu \mathrm{mol} / \mathrm{L}>0 \mu \mathrm{mol} / \mathrm{L}$. When the doses of MT were 50, 100, 150 and $200 \mu \mathrm{mol} / \mathrm{L}$, the POD activity of radish improved by $6.35 \%(p>$ $0.05), 23.62 \%(p<0.05), 6.74 \%(p>0.05)$ and $2.42 \%(p>0.05)$ respectively compared with the control. The SOD activity of radish was ranked as: $100 \mu \mathrm{mol} / \mathrm{L}>150 \mu \mathrm{mol} / \mathrm{L}>200 \mu \mathrm{mol} / \mathrm{L}>50$ $\mu \mathrm{mol} / \mathrm{L}>0 \mu \mathrm{mol} / \mathrm{L}$. When the doses of MT were 50,100, 150 and $200 \mu \mathrm{mol} / \mathrm{L}$, the SOD activity of radish improved by $17.26 \%(p>0.05), 35.20 \%(p<0.05), 18.97 \%(p>0.05)$ and $17.27 \%(p>0.05)$ respectively compared with the control. The CAT activity of radish was ranked as: $100 \mu \mathrm{mol} / \mathrm{L}>150$ $\mu \mathrm{mol} / \mathrm{L}>200 \mu \mathrm{mol} / \mathrm{L}>50 \mu \mathrm{mol} / \mathrm{L}>0 \mu \mathrm{mol} / \mathrm{L}$. When the doses of MT were 50, 100, 150 and 200 $\mu \mathrm{mol} / \mathrm{L}$, the CAT activity of radish improved by $98.49 \%(p>0.05), 132.52 \%(p<0.05), 114.82 \%(p$ $<0.05)$ and $103.69 \%(p>0.05)$ respectively compared with the control. MT also increased the soluble protein content of radish in all treatments compared with the control (Table 4). The ranked of soluble protein content was the same as the CAT activity. When the doses of MT were 50, 100, 150 and 200 $\mu \mathrm{mol} / \mathrm{L}$, the soluble protein content of radish increased by $20.05 \%(p>0.05), 40.60 \%(p<0.05)$, $25.31 \%(p>0.05)$ and $24.40 \%(p>0.05)$ respectively compared with the control.

\section{Conclusions}

Different concentrations (50, 100, 150 and $200 \mu \mathrm{mol} / \mathrm{L}$ ) of MT increased the biomass, chlorophyll content and antioxidant enzyme activity of radish seedlings under salt stress. When the concentration of MT was $100 \mu \mathrm{mol} / \mathrm{L}$, the biomass, chlorophyll content and antioxidant enzyme activity of radish seedlings got the maximums. Therefore, MT could relieve the damage of radish seedlings under salt stress, and the dose of $100 \mu \mathrm{mol} / \mathrm{L}$ was the best. 
Table 4 The antioxidant enzyme activity of radish

\begin{tabular}{|c|l|l|l|l|}
\hline $\begin{array}{c}\text { MT concentrations } \\
(\mu \mathrm{mol} / \mathrm{L})\end{array}$ & \multicolumn{1}{|c|}{$\begin{array}{c}\text { POD activity } \\
(\mathrm{U} / \mathrm{g} / \mathrm{min})\end{array}$} & $\begin{array}{c}\text { SOD activity } \\
(\mathrm{U} / \mathrm{g})\end{array}$ & $\begin{array}{c}\text { CAT activity } \\
(\mathrm{mg} / \mathrm{g} / \mathrm{min})\end{array}$ & $\begin{array}{c}\text { Soluble protein } \\
\text { content }(\mathrm{mg} / \mathrm{g})\end{array}$ \\
\hline 0 & $996.305 \pm 26.162 \mathrm{~b}$ & $1883.512 \pm 40.980 \mathrm{~b}$ & $19.704 \pm 9.289 \mathrm{~b}$ & $3.512 \pm 0.485 \mathrm{~b}$ \\
\hline 50 & $1059.567 \pm 28.087 \mathrm{ab}$ & $2208.537 \pm 60.064 \mathrm{ab}$ & $39.110 \pm 7.658 \mathrm{ab}$ & $4.216 \pm 0.523 \mathrm{ab}$ \\
\hline 100 & $1231.602 \pm 9.183 \mathrm{a}$ & $2546.473 \pm 288.101 \mathrm{a}$ & $45.815 \pm 3.571 \mathrm{a}$ & $4.938 \pm 0.204 \mathrm{a}$ \\
\hline 150 & $1063.492 \pm 19.642 \mathrm{ab}$ & $2240.896 \pm 132.046 \mathrm{ab}$ & $42.328 \pm 9.535 \mathrm{a}$ & $4.401 \pm 0.249 \mathrm{ab}$ \\
\hline 200 & $1020.408 \pm 28.862 \mathrm{~b}$ & $2208.884 \pm 135.8119 \mathrm{ab}$ & $40.136 \pm 8.658 \mathrm{ab}$ & $4.369 \pm 0.115 \mathrm{ab}$ \\
\hline
\end{tabular}

Values are means $( \pm \mathrm{SE})$ of three replicate pots. Different lowercase letters within a column indicate significant difference $(p<0.05)$.

\section{Acknowledgements}

This work was financially supported by the Undergraduate Thesis Breeding Program of Sichuan Agricultural University (2015).

\section{References}

[1] L.J. Wang, X.J. Huang, T.Y. Zhong and Z.G. Chen: Acta Geographica Sinica Vol. 66 (2011), p. 673. (In Chinese)

[2] G. Veeranagamallaiah, P. Chandraobulreddy, G. Jyothsnakumari and C. Sudhakar: Environmental and Experimental Botany Vol. 60 (2007), p. 239.

[3] D. Bartels and R. Sunkar: Critical Reviews in Plant Sciences Vol. 24 (2005), p. 23.

[4] D.X. Tan, R. Hardeland, L.C.Manchester, S.D. Paredes, A. Korkmaz, R.M. Sainz, J.C. Mayo, L. Fuentes-Broto and R.J.Reiter: Biological Reviews Vol. 85 (2010), p. 607.

[5] R. Dubbels, R.J. Reiter, E. Klenke, A. Goebel, E. Schnakenberg, C. Ehlers, H.W. Schiwara and W.Schloot: Journal of Pineal Research Vol. 18 (1995), p. 28.

[6] D.X. Tan, R. Hardeland, L.C. Manchester, A. Korkmaz, S. Ma, S. Rosales-Corral and R.J. Reiter: Journal of Experimental Botany Vol. 63 (2012), p. 577.

[7] K.M. Janas and M.M. Posmyk: Acta Physiologiae Plantarum Vol. 35 (2013), p. 3285.

[8] H.Y. Pan, X.Q. Zhang, J. Li, J. Zhao and H.Y. Bu: Journal of Northwest University (Natural Science Edition) Vol. 43 (2013), p. 238. (In Chinese)

[9] S.X. Liu, Y.Z. Huang, Z.J. Luo, Y.C. Huang, Q.L. Bao, P.P. Wang, B. Yuan and W.H. Li: Journal of Agricultural Resources and Environment Vol. 35 (2016), p. 1034. (In Chinese)

[10]L.Z. Wang anf Q.W. He: Chinese Radish (Science and Technology Literature Press, Beijing, China 2005). (In Chinese)

[11]Z.B. Hao, J. Cang and Z. Xu: Plant Physiology Experiment (Harbin Institute of Technology Press, Harbin, China 2004). (In Chinese) 